\title{
SEKSUALITAS: SUATU TINJAUAN ETIS KRISTIANI \\ TERHADAP PEMAHAMAN MAHASISWA FAKULTAS \\ TEOLOGI UNIVERSITAS KRISTEN INDONESIA TOMOHON \\ TENTANG HUBUNGAN SEKS
}

\author{
Allan Rifandi Sumeleh \\ Kerapatan Gereja Protestan Minahasa \\ sumelehallan@gmail.com \\ Diterima 8 Maret 2019 \\ Disetujui 14 April 2019
}

\begin{abstract}
Sexuality for some people is often considered a taboo thing to talk about but among young people this is important to know especially among students. Because in the era of openness of various information, it becomes interesting to discuss sexuality in various studies. The purpose of this study is to ethically study theological issues of sexuality in the understanding of students of the Theological Theology Faculty at the Indonesian Christian University of Tomohon by using descriptive qualitative research methods and using the theories of Malcolm Brownlee and J. L. Abineno and trying to study them in Bible view.
\end{abstract}

Keywords: Sexuality, Ethical Review of Christianity and Sexual Relations

\begin{abstract}
ABSTRAK
Seksualitas bagi sebagian orang sering dianggap hal yang tabuh untuk dibicarakan tetapi dikalangan Remaja Pemuda hal ini penting untuk diketahui apalagi dikalangan para mahasiswa. Karena di era keterbukaan berbagai informasi, menjadi menarik untuk membahas seksualitas dalam berbagai kajian. Tujuan Penelitian ini adalah untuk mengkaji secara Etis teologis masalah seksualitas dalam pemahaman mahasiswa Fakultas Teologi Teologi di Universitas Kristen Indonesia Tomohon dengan menggunakan metode penelitian Kualitatif deskriptif dan menggunakan teori Malcolm Brownlee dan J. L. Abineno dan berusaha mengkajinya dalam pandangan Alkitab.
\end{abstract}

Kata Kunci: Seksualitas, Tinjauan Etis Kristiani dan Hubungan Seks

\section{PENDAHULUAN}

Manusia adalah makhluk ciptaan Tuhan yang termulia berbeda dengan ciptaan lainnya. Dalam diri manusia terdapat potensi atau kemampuan rasio dan kemampuan akal budi yang lebih tinggi dibandingkan dengan ciptaan lain. Kemampuan rasio dan kemampuan akal budi inilah yang membedakan eksistensi dan kedudukan manusia dengan ciptaan lain.

Manusia sebagai subjek yang mengolah dan memanfaatkan sumber daya alam yang ada dan tersedia, karena di dalam diri manusia terdapat potensi-potensi yang dapat digunakan untuk mengolah dan memanfaatkan sumber daya alam yang ada dengan tujuan untuk meningkatkan 
kesejahteraan hidup. Jadi pembangunan bisa ada dan berlangsung karena upaya manusia dan terwujudnya cita-cita pembangunan, sumber daya manusia merupakan kekuatan.

Bangsa Indonesia dalam menjalankan pembangunan jangka panjang membutuhkan sumber daya manusia yang kreatif serta berpikir ke masa depan untuk kelangsungan hidup bangsa Indonesia. Dalam pelaksanaan pembangunan tersebut, faktor sumber daya alam dan sumber daya manusia sangatlah menentukan. Pada hakekatnya sumber daya alam adalah objek sedangkan sumber daya manusia adalah subjek.

Mengingat bahwa mengemban tugas pembangunan bukanlah tugas yang mudah, maka untuk kelangsungan pembangunan tersebut bangsa Indonesia membutuhkan generasi muda yang mampu berpikir dan bertindak demi masa depan. Dengan demikian, generasi muda harus dipersiapkan sejak dini baik dari Kaum muda dalam hubungannya dengan perkembangan dunia dewasa ini seringkali mengalami kendala dalam menghadapi pertumbuhan dan perkembangan mental dan spiritual. Sebab generasi muda pada dasarnya sangat senang berinteraksi dengan lingkungan dan situasi yang ada. Gagasan- gagasan dan harapan-harapan serta pandangan orang lain diinternalisasikan untuk mendukung identitas mereka pada taraf pertumbuhan dan perkembangan. ${ }^{1}$ Karena posisi seperti ini, nampaknya pemuda kurang menguasai dan mengendalikan diri sehingga mempengaruhi eksistensi mereka sebagai pemuda gereja. Sebab tidak jarang di tengah-tengah masyarakat maupun gereja terjadi penyimpangan prilaku di kalangan generasi muda, sehingga timbul masalahmasalah yang mengakibatkan adanya ketimpangan-ketimpangan sosial karena penyimpangan prilaku bahkan sampai pada penyimpangan seksual yang disebabkan oleh pemuda itu sendiri.

Penyimpangan seksual adalah aktivitas seksual yang ditempuh seseorang untuk mendapatkan kenikmatan seksual dengan tidak sewajarnya. Biasanya, cara yang digunakan oleh orang tersebut adalah menggunakan obyek seks yang tidak wajar. Penyebab terjadinya kelainan ini bersifat psikologis atau kejiwaan, seperti pengalaman sewaktu kecil, dari lingkungan pergaulan, dan faktor genetik. Berikut ini macam-macam bentuk penyimpangan seksual: 1. Penyalahgunaan Narkoba. 2. Pelacuran. 3. Penyimpangan seksual (homo, lesbian, biseksual, pedofil, sodomi, 
zina, seks bebas, transeksual). 4.Tindak Kriminal atau Kejahatan (perampokan, pencurian, pembunuhan, pengrusakan, pemerkosaan).

Situasi ini membuat pemudapemuda diperhadapkan pada nilai-nilai baru yang tidak selamanya benar dan sesuai dengan etika Kristen. Akibatnya dalam diri pemuda terjadi perubahan tingkah laku. Di satu pihak perubahan yang terjadi mengarah pada perkembangan yang positif, tetapi di pihak lain mengakibatkan terjadinya praktek-praktek yang menyimpang dalam kehidupan bermasyarakat. Ini diakibatkan karena pemuda tidak mampu menguasai diri dari pengaruh-pengaruh yang ada sehingga mempengaruhi identitas mereka sebagai pemuda gereja.

Untuk mengantisipasi terjadinya penyimpangan-penyimpangan perilaku di kalangan pemuda, termasuk didalamnya penyimpangan seksual. Orang tua, gereja harus memperhatikan pemuda dalam segala aspek kehidupannya sebagai generasi penerus. Keluarga sebagai lembaga terkecil dalam masyarakat merupakan tempat pertama seorang anak mendapatkan pendidikan termasuk didalamnya pendidikan seks.

Pemuda yang dimaksud adalah yang menurut masyarakat pada umumnya ialah mereka yang belum menikah dan yang tidak lagi termasuk anak-anak. Pemuda pada masanya sangat penting untuk diperhatikan karena pada masa ini mereka banyak mengalami perubahan dalam dirinya, baik dari segi fisiknya maupun mentalnya. Pemuda itu kreatif dalam menghasilkan ide-ide, gagasan-gagasan untuk masa depannya. Untuk mencapai ideide, gagasan-gagasannya, mereka mempunyai semangat yang tak pernah padam untuk mewujudkan hal yang diyakininya tersebut.

Dalam penelitian ini, yang dimaksud pemuda adalah mahasiswa. Penulis membatasi pada mahasiswa usia muda (17 tahun sampai dengan 25 tahun) dan yang belum menikah.

Mahasiswa adalah salah satu elemen penting yang diharapkan dapat melakukan perubahan dan memberikan kontribusi nyata terhadap bangsa dan negaranya. Menjadi mahasiswa seharusnya menjadi langkah awal yang nyata untuk melakukan perubahan. Rasa idealisme yang ada pada diri mahasiswa sudah seharusnya didukung oleh seluruh masyarakat sebagai penyalur aspirasi masyarakat untuk membawa bangsa ke arah yang lebih baik.

Kata Mahasiswa dibentuk dari dua kata dasar yaitu "maha" dan "siswa". Maha berarti besar atau agung, sedangkan siswa berarti orang yang sedang belajar. Kombinasi dua kata ini menunjuk pada 
suatu kelebihan tertentu bagi penyandangnya. ${ }^{2}$

Pada hakikatnya pergaulan diperlukan untuk penyempurnaan martabat manusia. Namun di situ tidak selalu mengarah pada kehidupan yang positif untuk pembangunan mental. Malah sebaliknya sering pergaulan itu berkibat negatif bahkan menghambat kelancaran jalinan hidup sosial.

Kian maraknya persoalan tentang seksualitas yang terus disoroti di kalangan pergaulan pemuda-pemudi karena tidak mengerti bahwa seksualitas adalah anugerah Allah bagi setiap manusia. Oleh karena itu harus di jaga sebagaimana anggota tubuh yang lain.

Sebagian mahasiswa Fakultas Teologi sebagai kaum muda tidak lepas dari kekurangpahaman tentang Seksualitas. Kenyataan ini berdampak pada penyalahgunaan seks.

\section{METODE}

1. Metode Penelitian Deskriptif

Dalam pelaksanaan penelitian ini penulis menggunakan metode penelitian deskriptif. Penelitian deskriptif adalah penelitian yang bermaksud untuk membuat

${ }^{2}$ http://blogspot.com/2012/11/membangkitkanspirit-gerakan-mahasiswa.html

${ }^{3}$ Sumadi Suryabrata, Metodologi Penelitian. Jakarta: Rajawali, 1989, 19

4 Sugiyono, Metode Penelitian Kombinasi (Mixed Methods). Bandung: Alfabeta, 2011,6 pencandraan (deskripsi) mengenai situasisituasi atau kejadian-kejadian. $^{3}$

a. Lapangan

Lapangan penelitian atau tempat penelitian di asrama dan pemondokan di mana tempat tinggal mahasiswa fakultas Teologi Universitas Kristen Indonesia Tomohon. Pemilihan tempat ini didasarkan bahwa responden umumnya mendiami tempat-tempat tersebut.

\section{b. Jenis Data Penelitian}

Ada dua jenis data, yakni kualitatif dan kuantitatif. Data kualitatif adalah data yang berbentuk kata, kalimat, gerak tubuh, ekspresi wajah, bagan, gambar dan foto. Sedangkan data kuantitatif adalah data yang berbentuk angka atau data yang diangkakan/scoring. ${ }^{4}$

Dalam penelitian ini, penulis menggunakan data kualitatif yang menghasilkan data-data deskriptif atau paparan dengan kata-kata secara terperinci yang tertulis atau lisan dari orang-orang dan perilaku yang dapat diamati. ${ }^{5}$ Singkatnya, penelitian deskriptif adalah menuturkan serta menggambarkan kenyataan yang ada. ${ }^{6}$

2. Teknik Pengumpulan Data

a. Obsevasi

\footnotetext{
${ }^{5}$ Lexi Moleong, Metode Penelitian Kualitatif. Bandung: PT. Remaja Karya, 1989,4

${ }^{6}$ Winarto Surakhmad, Pengantar Penelitian Ilmiah. Bandung: Tarsito, 1982, 139
} 
Penulis melakukan observasi atau mengamati langsung, yakni hadir bersamasama dengan mahasiswa dalam perkuliahan dan kegiatan-kegiatan di luar perkuliahan (ibadah-ibadah kerukunan mahasiswa) karena peneliti adalah mahasiswa Fakultas Teologi.

\section{b. Wawancara}

Untuk mendapatkan data yang akurat, maka penulis menggunakan jenis wawancara baku terbuka. Jenis wawancara ini adalah wawancara yang menggunakan seperangkat pertanyaan baku. Urutan pertanyaan, kata-katanya, dan cara penyajiannya pun sama untuk setiap responden. $^{7}$

c. Analisa Data

Kegiatan analisa adalah upaya memahami makna dari data yang diperoleh dan mulai mengidentifikasi data kemudian menguraikan data serta mengevaluasi tingkat kepercayaannya.

d. Penetapan Populasi dan Sampel

Dalam penelitian ini penulis menggunakan jenis populasi terbatas karena jumlah populasi diketahui secara pasti yaitu mahasiswa yang diteliti berjumlah 100 jiwa.

Populasi adalah keseluruhan subjek penelitian. ${ }^{8}$ Populasi diartikan sebagai wilayah generalisasi yang terdiri atas:

\footnotetext{
${ }^{7}$ Moleong, 1989. 188

8 Suharsimi Arikunto, Prosudur Penelitian. Jakarta: Rineka Cipta, 1997. 115
}

obyek/subyek yang mempunyai kualitas dan karakteristik tertentu yang ditetapkan oleh peneliti untuk dipelajari dan kemudian ditarik kesimpulannya. ${ }^{9}$

Sampel adalah sebagian atau wakil populasi yang diteliti. ${ }^{10}$ Teknik Sampel yang digunakan dalam penelitian ini ialah Sampel Random, atau Sampel Acak, Sampel Campur. Teknik sampling ini diberi nama demikian karena di dalam pengambilan sampelnya peneliti 'mencampur' subjek-subjek di dalam populasi sehingga semua subjek dianggap sama. $^{11}$

Populasi yang dimaksudkan di sini ialah para mahasiswa yang berada di Fakultas Teologi yang berjumlah 108 jiwa. Dari populasi tersebut penulis menetapkan 53 jiwa yang menjadi sampel, di mana 53 jiwa ini adalah mahasiswa Fakultas Teologi. Alasan penulis memilih 53 jiwa ini yakni, para responden ini mudah ditemui di pemondokan dan yang berada di asrama. Mahasiswa lainnya sulit ditemui karena mereka tidak tinggal di Tomohon. Dengan kata lain, para mahasiswa selain 53 jiwa ini tidak menetap dan tidak tinggal di Tomohon.

\begin{tabular}{|c|c|c|c|}
\hline & Perempua & Laki- & \\
& $\mathrm{n}$ & laki & \\
\hline
\end{tabular}

\footnotetext{
${ }^{9}$ Sugiyono, 2011:297

${ }^{10}$ Suharsimi Arikunto, 1997:117

${ }^{11}$ Suharsimi Arikunto, 1997:120
} 


\begin{tabular}{|c|c|c|c|}
\hline $\begin{array}{c}\text { Semeste } \\
\mathrm{r}\end{array}$ & Jumlah & $\begin{array}{c}\text { Jumla } \\
\mathrm{h}\end{array}$ & $\begin{array}{c}\text { Jumla } \\
\mathrm{h}\end{array}$ \\
\hline $\mathrm{I}$ & 7 & 3 & 10 \\
\hline III & 5 & 4 & 9 \\
\hline V & 5 & 4 & 9 \\
\hline VII & 8 & 3 & 11 \\
\hline VIIII & 9 & 5 & 14 \\
\hline \multicolumn{3}{|c|}{ Jumlah } & 53 \\
\hline
\end{tabular}

\section{KAJIAN PUSTAKA}

A. Pengertian Etika

Kata "Etika" dari bahasa Yunani kuno. Kata Yunani ethos, dalam bentuk tunggal mempunyai banyak arti: tempat tinggal yang biasa: padang rumput, kandang: kebiasaan, adat: akhlak, watak: perasaan, sikap, cara berpikir. Dalam bentuk jamak (ta etha) artinya adalah adat kebiasaan. $^{12}$

Dalam buku Etika Dasar, Franz Magnis-Suseno mengartikan etika sebagai ilmu untuk mencari orientasi. ${ }^{13}$ Artinya dengan etika manusia dibantu untuk menemukan orientasi dari sikap dan perilaku yang dilakukannya. Etika membantu manusia tidak hanya memutuskan untuk bersikap dan berlaku tertentu, tetapi juga membantu manusia menyadari dengan sungguh-sungguh dan benar mengapa ia bersikap dan berlaku demikian. Dengan kata lain etika

12 K Bertens, Etika. Jakarta: PT Gramedia Pustaka Utama 1994. 4 membantu manusia untuk mampu mempertanggungjawabkan keputusannya untuk bersikap dan berperilaku atau bertindak tertentu dalam hidupnya. Orientasi membantu manusia untuk melakukan sesuatu dengan arah dan tujuan yang jelas. Dengan demikian manusia tidak menjadi bingung di mana ia berada dan ke arah mana ia harus bergerak untuk mencapai tujuannya.

Ketika berbicara etika, pembicaraan tersebut tidak pernah lepas dari istilah "moral". Dengan kata lain, istilah atau kata "moral" senantiasa muncul dalam diskusidiskusi tentang etika. Dalam bagian ini akan dijelaskan secara khusus tentang arti dan makna dari istilah atau kata "moral" yang selalu muncul ketika kita berbicara tentang etika.

Kata "moral" berasal dari kata Latin "mos" (genetif= "moros") yang searti dengan kata Yunani "ethos", yakni adat, cara bertindak, tempat tinggal, kebiasaan. ${ }^{14}$ Kata "moral" selalu mengacu pada baikburuknya manusia sebagai manusia. Istilah "moral" tidak merujuk pada baik-buruknya manusia sebagai pelaku profesi tertentu, seperti sebagai dosen, sebagai penceramah, sebagai dokter, sebagai perawat, sebagai penulis. Dengan kata lain istilah "moral"

13 Bdk., Franz Magniz-Suseno, Etika Dasar, Masalah-masalah Pokok Filsafat Moral (Yogyakarta: Kanisius, 2002), hlm. 13.

${ }^{14}$ Harry Hamersma, Pintu Masuk.... 23 
merujuk pada inti terdalam atau hakikat manusia, yakni manusia sebagai manusia.

Selanjutnya akan ditinjau lebih dalam lagi bagaimana sebenarnya moralitas itu menurut pandangan para ahli. Dan pengertian tersebut dijadikan suatu acuhan untuk lebih memahami secara sederhana tentang moralitas itu bagi manusia, yaitu ajaran tentang yang baik dan buruk kelakuannya. Kita lihat pandangan beberapa ahli yaitu: Durkheim, seperti yang dikutip oleh A. Gunawan Setiardja, dalambukunya 'Dialektika Hukum Moral' mengatakan bahwa : apa yang disebut moral dan kesusilaan sesungguhnya hanyalah ikatan dari masyarakat sematamata. Mengapa sesuatu dikatakan buruk? Karena masyarakat melarangnya. Mengapa sesuatu itu dikatakan baik? Karena masyarakat menghendakinya. ${ }^{15}$

Jadi dari pandangan para ahli di atas, dapatlah penulis jelaskan bahwa penilaian moral terhadap seseorang bukan hanya dilihat dari sikap dan tindakan manusia melalui peran yang dilakukannya, akan tetapi ukuran moral dinilai dari segi kebaikan dan keburukan manusia sebagai manusia. Moralitas adalah sikap hati seseorang yang terungkap dalam tindakan lahiriah karena tindakan merupakan ungkapan sepenuhnya dari hati. Dengan

15 Setiardja A. Gunawan, Dialektika Hukum Moral (Kanisius: BPK Gunung Mulia, 1989). 15 demikian, moralitas itu terdapat disaat orang mengambil sikap yang baik karena ia menyadari eksistensinya selaku umat Allah. Dan ia sadar akan tugas dan tanggung jawab selaku umat yang percaya. Moralitas adalah sikap dan perbuatan baik yang benar-benar tanpa pamrih.

B. Seksualitas

J.M. Fuster dalam bukunya yang berjudul Teknik Mendewasakan Diri mengatakan bahwa : "Seks adalah suatu daya yang indah yang dianugerahkan oleh Sang Pencipta kepada kita untuk tujuan yang baik yaitu sebagai daya dorong penghayatan nilai-nilai cinta, penyerahan diri, pengabdian, korban, kesetiaan, yang semua itu membuahkan kebahagiaan, pertumbuhan pribadi dan semakin mendekatkan kepada Allah". ${ }^{16}$

Seks adalah ciptaan Tuhan dan merupakan anugerah yang paling indah. Untuk itu sebagai manusia haruslah mempergunakan anugerah Tuhan ini dengan tujuan yang baik, karena seks mempunyai nilai-nilai cinta, kesetiaan, pengabdian dan sebagainya. Dengan demikian, manusia tidak bisa menjadikan seks hanya untuk alat pemuas nafsu, manusia dituntut untuk lebih mendekatkan diri kepada Tuhan yang adalah Pencipta seks tersebut.

16 J.M. Fuster, Teknik Mendewasakan Diri (Yogyakarta : Kanisius, 1987). 14 
Selanjutnya Malcolm Brownlee mengatakan bahwa: "Seks tidak kotor atau najis, malah seks itu baik dan mulia. Seks bukan pokok yang tabu untuk dibicarakan, seks juga perlu dibicarakan dengan hormat karena seks diciptakan Tuhan."17

Di bawah ini, penulis mengemukakan pendapat para ahli mengenai seksualitas. J.L.Ch. Abineno: "Seksualitas mencakup hubungan yang biasa, hubungan batiniah antara laki-laki dan perempuan dalam pergaulan, dalam studi, dalam pekerjaan dan sebagainya" ${ }^{18}$

Menurut S. Kruyt: "Pengertian dari seksualitas lebih luas dari seks saja. Seksualitas merangkap hubungan batin antara sesama manusia, terutama antara dua orang yang jenis kelaminnya yang berbeda. Seksualitas tidak terbatas pada nafsu birahi, akan tetapi juga merangkap cinta dan sayang". ${ }^{19}$

Menurut Ny. Singgih D. Gunarsa dan Singgih D. Gunarsa: "Seksualitas meliputi segi-segi yang dapat digolongkan pada segi fisik yang terdiri dari biologis, fisiologis serta segi psikis yaitu emosi", ${ }^{20}$

Dari pandangan beberapa ahli di atas, ternyata ada pengembangan pengertian seksualitas yaitu hubungan

17 Malcolm Brownlee, Hai Pemuda Pilihlah (Jakarta : BPK Gunung Mulia, 1986) . 89

18 J.L.Ch. Abineno, Seksualitas dan Pendidikan Seksuil (Jakarta : BPK Gunung Mulia, 1982) hal. 9 antara laki-laki dan perempuan baik hubungan secara biologis, psikologis maupun hubungan secara sosial. Dengan demikian, seksualitas bukan hanya dipahami dari hubungan dua jenis kelamin yang berbeda ataupun hanya berbicara di sekitar jenis kelamin laki-laki dan perempuan. Akan tetapi seksualitas itu dipahami juga dalam hubungan batin antara sesama manusia baik dalam pergaulan, pekerjaan, dalam studi dan sebagainya yang ada kaitannya dengan cinta dan sayang.

Dalam melakukan aktivitas seksual dalam pernikahan, nafsu birahi dan cinta kasih selalu berada pada posisi yang sama. Kedua-duanya saling berkaitan dan tidak boleh dipisahkan satu dengan yang lain. Karena apabila dalam suatu pernikahan itu hanya terdapat kasih dan tanpa ada nafsu birahi maka pernikahan itu akan rusak, demikian juga sebaliknya. Apabila dalam pernikahan hanya ada nafsu birahi tanpa ada cinta kasih, maka pernikahanpun akan runtuh, karena hanya berfokus pada persetubuhan. Jadi kecenderungan seksuil dan cinta kasih selalu berjalan bersama, karena kedua-duanya adalah anugerah Tuhan sejak manusia diciptakan. Oleh karena itu, apa yang diciptakan oleh Tuhan

19 S. Kruyt. Pendidikan Seksuil Seri Keluarga Sejahtera (Jakarta : BPK Gunung Mulia, 1982) hal. 14

${ }^{20}$ Y. Singgih D. Gunarsa - Singgih D. Gunarsa, Psikologi Untuk Muda-Mudi (Jakarta : BPK Gunung Mulia, 1990) hal. 66 
harus diterima dengan ucapan syukur (1 Timotius 4:4-5). ${ }^{21}$

C. Menurut Kesaksian Alkitab

Secara umum Alkitab, baik Perjanjian Lama maupun Perjanjian Baru, tidak memiliki satu bagian tertentu yang membicarakan soal seks atau seksual. Memang jika dilihat sekilas dalam Alkitab nampaknya pembicaraan mengenai hal itu dapat ditemukan, tetapi hanya dibicarakan secara tidak langsung misalnya, dosa perzinahan, hawa nafsu, atau percabulan. Namun, jika yang dimaksud adalah pembicaraan mengenai "apa atau bagaimana seks itu" maka tidak ada satu bagian yang secara detail membicarakan hal itu. Meskipun demikian, persoalan mengenai "apa dan bagaimana seks itu" dapat dimengerti dari beberapa bagian ayat dalam Alkitab seperti berikut ini:

1. Perjanjian Lama

Allah menciptakan manusia sebagai makhluk yang paling mulia di antara ciptaan atau makhluk yang lain. Sebagai makhluk ciptaan Allah, manusia memiliki keistimewaan dan keunikan di antara makhluk yang ada. Manusia diberikan oleh Allah kemampuan untuk berpikir dan melakukan sesuatu, namun itu bukan berarti manusia diberikan kebebasan untuk mempergunakan serta menguasai hasil ciptaan Allah. Allah berfirman kepada manusia "beranak-cuculah dan bertambah banyak" (Kejadian 1:28). Itu berarti segala sesuatu yang diciptakan oleh Allah bagi manusia harus dipergunakan sebagai ciptaan Allah yang agung, termasuk seks. Tuhan menciptakan manusia laki-laki dan perempuan (Kejadian 1:27). Dialah yang pertama kali berpikir tentang seks dan menciptakannya sebagai bagian dari rencana-Nya yang agung. Dengan demikian Allah menciptakan manusia sebagai makhluk seksual. ${ }^{22}$ Narasi penciptaan (karya sumber $\mathrm{P}$ sesudah pembuangan) menekankan bahwa manusia diciptakan sebagai makhluk seksual. Manusia diciptakan sebagai laki-laki (ish) dan perempuan (ishshah) dan dalam perbedaan seks itu mereka mencerminkan Allah : "maka Allah menciptakan manusia itu menurut gambar-Nya, menurut gambar Allah diciptakan-Nya dia; laki-laki dan perempuan diciptakan-Nya mereka” (Kejadian 1:27). Itu berarti seksualitas tidak hanya sesuatu yang baik, tetapi sekaligus mencitrakan kesucian dan kekudusan Allah. Narasi kedua (karya sumber Y dari abad ke 9 Seb. Kristus) menekankan alasan mengapa dan untuk apa seksualitas diciptakan. Perempuan diciptakan supaya laki-laki tidak kesepian dan membutuhkan teman hidup (Kejadian 2:18). Tujuannya supaya terjadi komunitas manusia yang 
dinyatakan dalam kesatuan daging dan tulang (Kejadian 2:22-24). ${ }^{23}$

Sesudah menciptakan manusia Allah melihat bahwa segala yang dijadikanNya termasuk kelamin manusia sungguh amat baik (Kejadian 1:31). Hal itu berarti seksual diberikan sebagai karunia Tuhan kepada manusia. Seks harus diterima dengan ungkapan syukur bukan dengan rasa takut atau malu. ${ }^{24}$ Karena pemahaman yang salah tentang seksual adalah hal yang sangat keliru. Bagi orang percaya seksual adalah hal yang wajar bagi suami-isteri karena itu kenikmatan dalam persetubuhan yang merupakan kasih karunia Allah dan bukan suatu kebijaksanaan dan kepandaian manusia. Dengan demikian untuk menjawab kasih karunia Allah, maka melakukan hubungan seksual hanya dalam pernikahan yang kudus karena di dalamnya Allah mempersatukan dua manusia dalam satu daging.

Pernikahan merupakan persekutuan yang dilaksanakan atas dasar kasih antara laki-laki dan perempuan untuk melakukan kehendak Allah sebagai anugerah Ilahi maupun sebagai tuntutan Ilahi. ${ }^{25}$ Dengan tegas dan jelas Salomo mengatakan bahwa mereka yang melakukan hubungan seks sebelum nikah adalah orang yang tidak berakal budi, karena tindakan tersebut

\footnotetext{
23 Robert P. Borrong, Etika Seksual Kontemporer (Bandung : Ink Media 2006) . 2

${ }^{24}$ Brownlee Malcolm, 87
}

adalah perzinahan bnd. Amsal 6:32 "siapa melakukan zinah tidak berakal budi; orang yang berbuat demikian merusak diri”. Kemudian Salomo juga memberi nasehat untuk menjauhi dari mereka yang selalu melakukan kejahatan, "jauhkanlah jalanmu dari pada dia dan jangan menghampiri pintu rumahnya" (Amsal 5:8). ${ }^{26}$

Selanjutnya dalam Amsal 5:9 mengatakan bahwa "supaya engkau jangan menyerahkan keremajaanmu kepada orang lain dan tahun-tahun umurmu kepada orang kejam", demikian juga dalam ayat 17 mengatakan, "biarlah itu menjadi kepunyaanmu sendiri, jangan juga menjadi kepunyaan orang lain". Dengan penjelasan beberapa ayat di atas, dapatlah kita memahami bahwa beberapa ayat tersebut memberi argumentasi bahwa menjaga diri serta menguasai diri dari berbagai macam godaan di kalangan pemuda sangat sulit untuk dilakukan. Oleh karena itu, demi mempertahankan kekudusan yang diberikan Allah bagi manusia hindarilah dan jauhkanlah dirimu dari orang-orang kejam agar keremajaan yang dimaksudkan oleh Salomo tetap terpelihara. Karena hal itu juga mempengaruhi kehidupan suamiistri dalam rumah tangga dan bukan tidak mungkin dalam pernikahan terjadi perselisihan di antara mereka sebagai

\footnotetext{
${ }^{25}$ Verkuyl J. 109

${ }^{26}$ White Jerry, Kejujuran Moral dan Hati Nurani (Jakarta : BPK Gunung Mulia, 1987). 166
} 
suami-isteri. Oleh karena itu menguasai diri dalam pergaulan dimasa muda serta menjaga kemurnian diri sebagai pemuda dapat menciptakan kebahagiaan dalam persekutuan sebagai suami-istri. Di dalamnya tercipta sifat keterbukaan serta saling mengenal dengan tidak ada rasa takut, malu apalagi rasa berdosa terhadap pencipta.

Dalam I Samuel 2:22-25 : "Eli sudah sangat tua. Apabila didengarnya segala sesuatu yang dilakukan anakanaknya terhadap semua orang Israel dan bahwa mereka itu tidur dengan perempuanperempuan yang melayani di depan pintu Kemah Pertemuan, berkatalah ia kepada mereka: "mengapa kamu melakukan halhal yang begitu, sehingga kudengar dari segenap bangsa ini tentang perbuatanperbuatanmu yang jahat itu? Janganlah begitu, anak-anakku. Bukan kabar baik yang kudengar itu bahwa kamu menyebabkan umat Tuhan melakukan pelanggaran. Jika seorang berdosa terhadap yang lain, maka Allah yang akan mengadili; tetapi jika seorang berdosa terhadap Tuhan, siapakah yang menjadi perantara baginya?" tetapi tidaklah didengarkan mereka perkataan ayahnya itu, sebab Tuhan hendak mematikan mereka.

2. Perjanjian Baru

Dalam Injil Yohanes 8:11b dan c dikatakan bahwa: "Lalu kata Yesus: Aku pun tidak menghukum engkau. Pergilah dan jangan berbuat dosa lagi mulai dari sekarang”. Hal ini mengenai seorang perempuan yang kedapatan melakukan perzinahan. Semua manusia tidak sempurna yang tidak luput dari kesalahan dan dosa. Demikian juga halnya dengan teks pembacaan di atas tentang seorang perempuan yang berbuat kesalahan. Akan tetapi, perkataan Yesus menurut Injil Yohanes 8: 11c "Pergilah dan jangan berbuat dosa lagi mulai dari sekarang”. Perkataan Yesus ini adalah suatu keharusan atau perintah yang harus dilakukan oleh perempuan dalam cerita tersebut.

Pasti timbul pertanyaan di antara kita, apakah perempuan ini diselamatkan pada saat ia meninggalkan Kritsus? Kita dapat mempercayai bahwa ia pasti selamat. Kita dapat menduga demikian karena perempuan tersebut tidak meninggalkan Yesus ketika ia mempunyai kesempatan melakukannya dan juga karena ia menyebut Yesus sebagai Tuhan.

Perempuan dalam teks Injil Yohanes 8:11 adalah salah satu contoh manusia yang tidak sempurna, yang tidak luput dari kesalahan dan dosa. Begitu juga dengan kita yang adalah manusia yang penuh dengan kesalahan dan dosa. Akan tetapi menurut teks tersebut, kesalahan dan dosa itu bisa diperbaiki dengan cara tidak berbuat atau mengulang kembali kesalahan dan dosa mulai dari sekarang. Hal ini menunjukkan bahwa ketika kita sudah 
melakukan kesalahan dan dosa, kita diperintahkan untuk janganlah melakukan hal tersebut. Inipun harus direalisasikan dalam kehidupan kita sebagai umat yang percaya kepada Yesus Kristus yang adalah Kepala Gereja dan Tuhan Dunia.

\section{HASIL DAN PEMBAHASAN}

Hasil kesepakatan antara penulis dengan para responden ialah data yang didapat melalui hasil wawancara adalah bersifat rahasia. Dengan kata lain, mereka tidak ingin namanya dimuat dalam penulisan ini. Dari hasil penelitian lapangan mengenai pemahaman mahasiswa tentang hubungan seks sebelum menikah maka secara umum penulis menguraikannya sebagai berikut:

Ada 53 Mahasiswa yang paham dan dapat menjelaskan tentang seks serta masalah seksualitas ini dalam hubungan pacaran mereka. Sebagian besar dari mereka mengerti dan memahami etis tidaknya masalah seks ketika dilakukan sebelum menikah. Tetapi ada juga yang memahami hal itu atas dasar suka sama suka.

\section{Analisa Data Penelitian}

Berdasarkan analisa yang telah dilakukan terhadap hasil penelitian, maka penulis dapat merangkum pandangan para responden mengenai hubungan seks, bahwa

a) Terminologi mengenai hubungan seks masih tidak sepaham di antara mahasiswa tapi juga masih menampakkan hal yang tidak konsisten. Ini bisa dilihat khususnya mahasiswa yang menjawab hubungan seks sebagai perjumpaan yang biasa tapi ketika berbicara mengenai hubungan seks sebelum nikah maka mereka juga merujuk kepada hubungan kelamin/persetubuhan antara lelaki dan perempuan.

b) Bagi mahasiswa yang menjadi responden, hubungan seks bisa dilakukan asalkan berdasar pada cinta dan tanggung jawab. Para responden tahu bahwa hubungan seks sebelum nikah adalah terlarang dan muncul oleh sebab-sebab yang negatif tapi tetap bisa dilakuan dengan dasar cinta dan tanggung jawab.

c) Pengetahuan mengenai seks tidak banyak membantu dalam pencegahan terjadinya hubungan seks di luar nikah. Pengetahuan tersebut bisa membuat mahasiswa tidak melakukan hubungan seks sebelum nikah namun bisa juga membuat terpicu untuk melakukan hal tersebut. Yang terutama bagi mereka adalah landasan dalam melakukan hubungan seks adalah cinta kasih.

\section{Tinjauan Etis Kristiani Terhadap Pemahaman Mahasiswa Fakultas Teologi Tentang Hubungan Sex}

Untuk lebih memahami tentang etika, haruslah membedakannya dari ajaran 
moral. Ajaran moral dimaksud ajaranajaran, wejangan-wejangan, khotbahkhotbah, patokan-patokan, kumpulan peraturan dan ketetapan entah lisan atau tertulis, tentang bagaimana manusia harus hidup dan bertindak agar ia menjadi manusia yang baik. $^{27}$

Menurut Kamus Besar Bahasa Indonesia yang baru (Deprtemen Pendidikan dan Kebudayaan, 1988), etika dijelaskan dengan membedakan tiga arti: 1) ilmu tentang apa yang baik dan apa yang buruk dan tentang hakda kewajiban moral (akhlak). 2) kumpulan asas atau nilai yang berkenaan dengan akhlak. 3) nilai mengenai benar dan salah yang dianut suatu golongan masyarakat. ${ }^{28}$

Dengan demikian, kata etika bias dipakai dalam arti, pertama: nilai-nilai dan norma-norma moral yang menjadi pegangan bagi seseorang atau suatu kelompok dalam mengatur tingkah lakunya. Kedua: etika berarti kumpulan asas atau nilai moral. Yang dimaksud di sini adalah kode etik. Ketiga: etika mempunyai arti ilmu tentang yang baik atau buruk. ${ }^{29}$

Dari beberapa pendapat tentang pengertian etika di atas, maka jelaslah bahwa tinjauan etis kistiani adalah suatu tinjauan tentang sikap yang baik dan yang

\footnotetext{
${ }^{27}$ Franz Magnis Suseno, Etika Dasar. 14

${ }^{28}$ K. Bertens, Etika, Jakarta: PT Gramedia Pustaka Utama 1994. 6

${ }^{29}$ K. Bertens, Etika, 6.
}

buruk dari seseorang atau sekelompok orang Kristen dengan berdasarkan pada kehendak Allah yang nyata dalam karya dan keteladanan Yesus Kristus. Sedangkan pengertian kata tinjauan dimaksudkan ialah suatu pemikiran kritis terhadap sesuatu hal kemudian memunculkan suatu pandangan baru berdasarkan kebenaran. Selajutnya, menurut Eka Darmaputera tentang penilaian etis ialah, etika Kristen harus bertitik-tolak pertama-tama pada kebaikan dan keistimewaan manusia sebagai gambar Allah. Setiap keputusan dan penilaian etis secara kristiani harus bersifat menghargai dan menghormati hakekat manusia yang istimewa ini. ${ }^{30}$

Pengertian tinjauan etis dari J.L. Ch Abineno mengatakan bahwa: dalam penilaian etis tindakan atau perbuatan orang ditempatkan di bawah tinjauan tentang yang baik dan yang buruk. ${ }^{31}$

Di era globalisasi ini kedudukan atau posisi kaum muda masih menjadi topik pembicaraan yang hangat dari berbagai pihak karena kaum muda adalah generasi yang menjadi harapan penentu keberhasilan pembangunan. Tidak jarang pula generasi muda disebut-sebut sebagai tulang punggung gereja yang kelak akan melanjutkan pekerjaan pemberitaan Injil.

\footnotetext{
${ }^{30}$ Eka Darmaputera, 102

${ }^{31}$ J.L.Ch. Abineno, Sekitar Etika dan Soalsoal Etis. Jakarta: BPK Gunung Muia, 1994. 5
} 
Namun perlulah disadari bahwa pemuda sebagai harapan bangsa, negara dan harapan gereja seperti terlempar dalam krisis yang kompleks. ${ }^{32}$ Sebagai salah satu contoh, pelanggaran moral dikalangan muda-mudi semakin hebat. ${ }^{33}$ Inilah akibat dari ciri khas pemuda yang sangat senang dengan gaya hidup modern. Mereka ingin hidup bebas sebagaimana layaknya manusia yang telah tumbuh dewasa. Pemuda yang mulai beralih dari sikap ketergantungan pada keluarga ke sikap membangun diri sendiri, ${ }^{34}$ bukan berarti tidak lagi memerlukan perhatian dan bimbingan dari orang tua. Justru pada masa inilah perhatian orang tua harus sepenuhnya dipusatkan pada pemuda. Dijelaskan kembali kepada pemuda bahwa seks diciptakan oleh Tuhan sebagai bagian dari rencana-Nya yang Agung untuk kehidupan dan kebahagiaan manusia. Namun bukanlah berarti manusia boleh menyalahgunakan seks sebagai pemberian Allah itu. Oleh karena seks adalah ciptaan Tuhan yang baik, maka manusia harus menerimanya dengan syukur dan bertanggung jawab, artinya melakukan hubungan seksual hanya selayaknya bagi

\footnotetext{
${ }^{32}$ J.J.G.Sondakh, Makna Pergaulan MudaMudi Kristen di Tengah Perubahan Nilai Seksual Masa Kini. Educatio Christi No.6. Tahun 1994. 49

${ }^{33}$ J.J.G.Sondakh.

34 J.P.Pinontoan,S., Perkembangan Sikap Religius Remaja dan Pemuda. Educatio Christi No. 11. Tahun 1998. 5
}

mereka yang telah dipersatukan dalam nikah yang kudus.

Untuk menjaga agar supaya tidak terjadi hubungan seksual sebelum nikah, maka pergumulan doa sangatlah penting. Di samping itu perlu pengendalian diri, karena hanya dengan mengendalikan diri orang takkan terjerumus dalam nafsu erotis. $^{35}$ Manusia diciptakan menurut 'gambar dan rupa Allah', justru karena itulah kekudusan pribadi harus dijaga. Tuhan adalah Khalik dan manusia adalah makhluk, oleh karena itu segala ciptaan Sang Khalik jangan dirusak oleh ciptaan termasuk pribadi manusia. ${ }^{36}$ Jadi manusia dalam hal ini orang muda harus mampu mengendalikan diri, bergumul dalam doa untuk menjaga kekudusan diri sebagai ciptaan Sang Khalik. Dengan demikian jelaslah bahwa melakukan hubungan seksual sebelum nikah adalah tindakan penyelewengan terhadap maksud Tuhan pada saat menciptakan seks bagi kehidupan umat manusia. Hubungan seks sebelum nikah merusak hubungan yang harmonis antara manusia dengan Allah Sang Khalik dan antara manusia dengan sesama. Selain itu juga seks sebelum nikah merusak masa depan manusia itu sendiri.

35 J.J.G.Sondakh, Educatio Christi No.6. Tahun 1994. 61

36 J.J.G.Sondakh, Educatio Christi No.6. Tahun 1994. 


\section{Refleksi Teologis}

Seksualitas adalah karunia Tuhan yang khusus dimaksud untuk memberikan keutuhan dan kepenuhan dalam setiap pribadi manusia. ${ }^{37}$ Setiap manusia harus menerima dan mengakui serta menghargai seksualitas itu dalam dirinya. Tidak mau mengakui dan menghargai seksualitas akan mengakibatkan penggunaaan yang tak sesuai atau penyalahgunaan seks yang berakhir pada penghancuran diri. ${ }^{38}$ Seksualitas bukan diciptakan untuk kesenangan belaka, tetapi untuk maksud yang lebih mulia daripada itu yakni untuk memperkuat hubungan antara suami dan isteri. $^{39}$

Seks disalahgunakan dan sering dipandang sebagai sesuatu yang mengancam hubungan kita dengan Tuhan, daripada sesuatu yang direncanakan oleh Tuhan untuk memperindah kehidupan sebagai anak-anaknya. ${ }^{40}$ Manusia hanya ingin melakukan aktivitas seksualnya untuk kesenangan dan kenikmatannya, akan tetapi aktivitas seksual yang bertujuan untuk membentuk hubungan intim dan akrab terabaikan.

Dalam konteks ciptaan Allah, seks hanya diterima dan layak bagi suami-istri yang sah. Karena hubungan seks bagi

${ }^{37}$ Agudo Philomena, Aku Memilih Engkau. Kanisius 1998. 95

${ }^{38}$ Agudo Philomena, Aku Memilih Engkau.

${ }^{39}$ Abineno, J. L. Ch. Perkawinan. suami-isteri sebagai karunia Tuhan dan anugerah yang diberikannya bagi manusia. Hubungan seks dikalangan pemuda, oleh Alkitab dipandang sebagai suatu tindakan yang merusak hubungan manusia dengan Allah. Manusia bukan diberikan kebebasan untuk mempergunakan hasil ciptaan-Nya bagi kita dan bukan pula menyalahgunakan hasil ciptaan-Nya. Menyalahgunakan ciptaan-Nya (termasuk penyimpangan seks) itu sama halnya dengan merusak kekudusan yang diberikan Allah bagi kita selaku umat-Nya.

Menyalahgunakan ciptaan Allah termasuk penyimpangang seks, sering dihubungkan dengan perbuatan "dosa tubuh, hawa nafsu, kecemaran, percabulan dan kenajisan” (Roma 6:12, Galatia 5:19, Kolose 3:5). Beberapa daftar dosa dalam Perjanjian Baru menempatkan penyimpangan seks sama arti dengan dosadosa lain seperti, penyembahan berhala, kebencian, iri hati, pencurian dan kemabukan (I Korintus 6:9-10, Galatia 5:19-22). Bagian-bagian Alkitab ini mengatakan bahwa sifat yang mendasari penyimpangan seks sama arti dengan penyembahan berhala dan pencurian. ${ }^{41}$

Hubungan seks sebelum nikah ataupun penyimpangan seks tergolong pada

${ }^{40}$ Brownlee Malcolm, hal. 87-88
${ }^{41}$ Miles Hebert J, Sebelum Menikah Fahamilah Dulu Seks (Jakarta : BPK Gunung Mulia, 1992) hal. 200 
tindakan dosa tubuh, hawa nafsu, kecemaran, percabulan dan kenajisan. Penyimpangan seks sama arti dengan penyembahan berhala, kebencian, iri hati, mabuk dan pencurian. Dengan demikian, pemuda yang melakukan hubungan seks sebelum nikah adalah berdosa seperti yang diungkapkan di atas. Oleh karena itu untuk menghindari tindakan-tindakan tersebut, maka dalam melakukan hubungan seks ialah mereka yang telah menikah atau sebagai suami-isteri sah yang diakui oleh masyarakat dan gereja.

\section{KESIMPULAN}

Seks adalah anugerah Allah kepada manusia. Dengan demikian, seks haruslah dipahami sebagai sesuatu hal yang mulia. Karena seks adalah anugerah Allah, maka manusia dituntut agar melakukannya dengan baik dan benar.

Berbicara tentang seks berarti berbicara Allah yang adalah pencipta. Dengan demikian, berbicara tentang seks juga adalah keharusan semua manusia untuk mengetahui, memahami, dan mendialogkannya dalam kehidupan seharihari.

Melakukan hubungan seks sebelum nikah adalah suatu hal yang tidak baik, tidak benar untuk dilakukan, bertentangan dengan ajaran Gereja, merusak hubungan harmonis antara Allah dengan manusia, merusak masa depan manusia itu sendiri.
Dalam pemahaman iman Kristen melakukan hubungan seks sebelum nikah menghambat berkat. Hubungan seks haruslah dipandang sebagai suatu hal yang baik, dalam hal ini perkenalan antara perempuan dan laki-laki dalam konteks relasi dialog sesama manusia.

\section{DAFTAR PUSTAKA}

Abineno, J. L. Ch. Diaken. Jakarta: BPK Gunung Mulia, 1994.

dan Pekerjaannya. Jakarta: BPK Gunung Mulia 1994.

Sekitar Etika dan Soalsoal Etis. Jakarta: BPK Gunung Mulia, 1994.

Pendidikan Seksuil. Jakarta: BPK Gunung Mulia, 1982.

Perkawinan (Jakarta : BPK Gunung Mulia 1983).

Annie Jaubert. Mengenal Injil Yohanes. Yogyakarta : Kanisius 1980.

Arikunto, Suharsimi. Prosudur Penelitian. Jakarta: Rineka Cipta, 1997.

Bertens, K. Etika. Jakarta: PT. Gramedia Pustaka Utama, 1994.

Borrong, Robert P. Etika Seksual Kontemporer. Bandung: Ink Media, 2006.

Brownlee, Malcolm. Hai Pemuda Pilihlah. Jakarta: BPK Gunung Mulia, 1986. 
Fuster, J.M. Teknik Mendewasakan Diri. Yogyakarta: Kanisius, 1987.

Homrighausen E. G. dan I. H. Enklaar, Pendidikan Agama Kristen. Jakarta: BPK Gunung Mulia, 1987.

White, Jerry. Kejujuran Moral dan Hati Nurani. Jakarta: BPK Gunung Mulia, 1987.

James T, Burtchael. Keputusan Untuk Menikah (Yogyakarta : Kanisius 1990).

J.J.G.Sondakh, Makna Pergaulan MudaMudi Kristen di Tengah Perubahan Nilai Seksual Masa Kini. (Educatio Christi No.6. Tahun 1994).

J.P.Pinontoan,S., Perkembangan Sikap Religius Remaja dan Pemuda. (Educatio Christi No. 11. Tahun 1998).

Kaunang, K. A. et. al. Jerih Payahmu Tidak Sia-sia. Tomohon, 2012.

Kees Maas. Teologi Moral Seksualitas. Bogor: Nusa Indah, 1998.

Kruyt, S. Pendidikan Seksuil Seri Keluarga Sejahtera. Jakarta: BPK Gunung Mulia, 1982.

Lembaga Biblika Indonesia "Tafsir Perjanjian Baru: Injil dan Suratsurat Yohanes". Yogyakarta: Kanisius, 1981.

Moleong, Lexi. Metode Penelitian Kualitatif. Bandung: PT. Remaja Karya, 1989.
Parrinder, Geofrey. Teologi Seksual. Yogyakarta: Penerbit LkiS, 2005.

Poerwardarminta, W.J.S. Kamus Umum Bahasa Indonesia. Jakarta: PN. Balai Pustaka, 1985.

Purwa Hadiwardoyo Al. Moral dan Masalahnya. Yogyakarta: Kanisius, 1990.

Philomena Agudo. Aku Memilih Engkau (Yogyakarta : Kanisius 1998).

Pusat Pembinaan dan Pengembangan Bahasa, Kamus Besar Bahasa Indonesia. Jakarta: P.N. Balai Pustaka, 1990.

Shelton, Ch. M. Spiritual Kaum Muda. Yogyakarta: Kanisius, 1987.

Singgih D Y. Gunarsa - Singgih D. Gunarsa, Psikologi Untuk MudaMudi. Jakarta: BPK Gunung Mulia, 1990.

Anak, Remaja dan Keluarga. Jakarta: BPK Gunung Mulia, 1995.

Sugiyono. Metode Penelitian Kombinasi (Mixed Methods). Bandung: Alfabeta, 2011.

Sujanto Agus. Psikologi Perkembangan. Jakarta: Aksara Baru 1984.

Surakhmad Winarto. Pengantar Penelitian Ilmiah. Bandung: Tarsito, 1982.

Suryabrata Sumadi. Metodologi Penelitian. Jakarta: Rajawali, 1989.

Ukur dan Cooley. Jerih dan Juang. Jakarta: Lembaga Penelitian Studi DGI 2979. 
Verkuyl, J. Etika Kristen Seksuil. Jakarta: BPK Gunung Mulia, 1973.

Wuwungan, O. E.Ch. Bina Warga; Bunga Rampai Pembinaan Warga Gereja. Jakarta: BPK. Gunung Mulia, 1994.

Website

http://blogspot.com/2012/11/membangkitk an-spirit-gerakan-mahasiswa.html http://blogspot.com/2014/08/istilahpenyimpangan-seksual.html

Dokumen

BPS. GMIM, Tata Gereja GMIM dan Penjelasannya bagian IV. 